
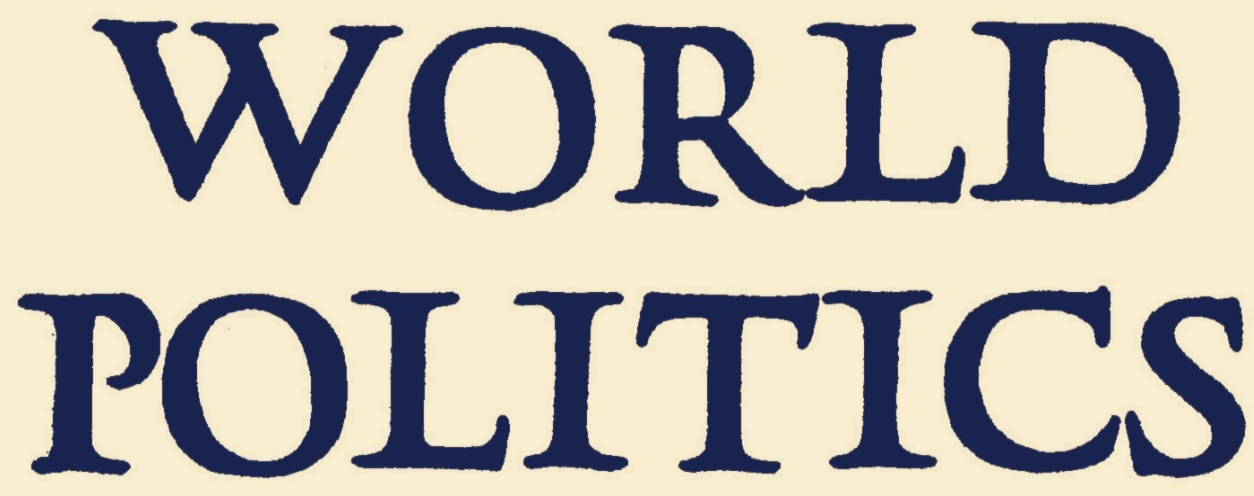

A Quarterly Fournal of

International Relations

Volume IX, Number 2

January 1957

Price $\$ 6.00$ per year 
UNDER THE EDITORIAL SPONSORSHIP OF

CENTER OF INTERNATIONAL STUDIES

PRINCETON UNIVERSITY

PUBLISHED BY PRINCETON UNIVERSITY PRESS

EDITORIAL BOARD

Frederick S. Dunn, Chairman

Bernard C. Cohen, Managing Editor

Jzan MacLachlan, Assistant Managing Editor

Kraus Knorr, Review Article Editor

Percy E. Corbetr

Wriliam T. R. Fox

Gordon A. Craig Edgar S. Furniss, JR.

ADVISORY EDITORS

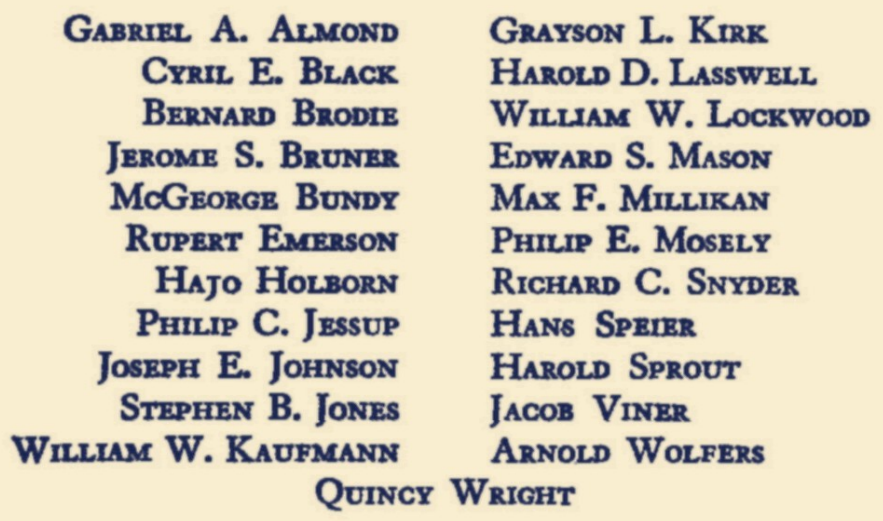

The oditors invite the submission of articles bearing upon problems of international relations. Editorial communications and manuscripts should be addressed to WORLD Pourrics, Woodrow Wilson Hall, Princeton, N.J.

Subscriptions: WORLD POLITICS, Woodrow Wilson Hall, Princeton, N.J.

Advertising: WORLD POLITTCS, Box 23I, Princeton University Press, Princeton, N.J.

WORLD POLITICS is indexed by the International Index to Periodicals, and abstracts of its articles appear in International Political Science Abstracts.

Statements of fact and opinion appearing in WORLD POLITICS are made on the responsibility of the authors alone, and do not imply the endorsement of the editors or publishers.

Copyright, 1957, by Princeton University Press

WORLD POLITICS. Published quarterly by Princeton University Press. January 1957. Vol. IX, No. 2. Entered as Second Class matter in the Post Office at Princeton, New Jersey, under the Act of March 3, 1879. Printed in the United States of America by Princeton University Press. Subscriptions \$6.00 per year (two years \$10.00); single copies \$2.00. Foreign postage 25 cents additional per year. 


\section{WORLD POLITICS}

Voi. IX

JANUARY 1957

No. 2

CONTENTS

Varieties of Worldly Wisdom

C.A.W.Manning 149

Economic Growth, Coercion, and Freedom

Karl de Schweinitz, Jr. $\quad 166$

Paris from EDC to WEU

Nathan Leites and Christian de la Malène

193

The Davies Mission and United States-Soviet

Relations, 1937-I94I

Richard H. Ullman

220

Review Articles

In Praise of Political Science

Charles E. Lindblom 240

Progress in the Theory of Economic Progress

Tibor Scitovsky 254

On Universal History

E. Harris Harbison 260

On Comparative History

Bert F. Hoselitz 267

A New Future for World War II?

Brigadier General S. F. Giffin, USAF 280

Africa: Scholarship and Policy

Lloyd A. Fallers 287

The Crisis of Modern Socialism

Kurt L. Shell 295

The Contributors 


\section{THE CONTRIBUTORS}

C. A. W. Manning has held the Chair of International Relations at the London School of Economics since $193^{\circ}$ and was formerly a member of the League of Nations Secretariat. His report, The University Teaching of Social Sciences: International Relations, was published by UNESCO in 1954 .

Kard de Schweinitz, Jr., Associate Professor of Economics at Northwestern University, is co-author, with Kenneth W. Thompson, of Man and Modern Society (1953). He continues to work on a comparative study of industrial revolution.

Nathan Leites is Visiting Lecturer in the Department of Political Science at Yale and a member of the Social Science Division of The RAND Corporation. Among his publications are $A$ Study of Bolshevism (1953) and, with Elsa Bernaut, Ritual of Liquidation: The Case of the Moscow Trials (1954).

Christian de la Malìne is Secretary of the Groupe des Républicains Sociaux in the Council of the Republic of France.

Richard H. Ullman, in his second year at Oxford as a Rhodes Scholar, is a member of New College and the holder of a Studentship at Nuffield College. He is engaged in a study of Anglo-Soviet relations in the period 1917-1924.

Charles E. Lindblom, Associate Professor of Economics at Yale University, published Politics, Economics and Welfare with Robert A. Dahl in 1953. He is currently employing the professional tools and insights of economists in an analysis of political bargaining among government officials and other political leaders.

Tibor Scrtovsky is Professor of Economics at Stanford University. He is preparing a volume of essays dealing with Western economic integration.

E. Harris Harbison is Henry Charles Lea Professor of History at Princeton University. His field is sixteenth-century European history and his most recent book, The Christian Scholar in the Age of the Reformation, appeared in the fall of 1956.

Bert F. Hoselitz, Professor of the Social Sciences at the University of Chicago, is editor of the quarterly journal Economic Development and Cultural Change. One of the contributors to The Progress of Underdeveloped Areas (1952), he is at work on a book with the tentative title, Economic Growth and Social Structure.

Brigadier General S. F. Giffin, USAF, has been Vice Commandant of the Air War College at Maxwell Air Force Base, Ala., since 1954. His former assignments include service with the Tactical Air Command in the China Theater during World War II and several subsequent years at headquarters of the US European Command.

Lloyd A. Fallers is Director of the East African Institute of Social Research in Kampala, Uganda. The author of Bantu Bureaucracy (1956), he is collaborating with other members of the Institute on a study of patterns of emerging African leadership in Buganda and in Nyanza Province of Kenya.

Kurt L. Shell is Assistant Professor of Political Science at Harpur College of the State University of New York. He completed his doctoral dissertation in 1955 at Columbia University, where he was an instructor in the Department of Government. 